\title{
FANTASMAS Y JARDINES: UNA FAMILIA LEJANA
}

\author{
POR \\ MARGO GLANTZ \\ Universidad Nacional Autónoma de México
}

Carlos Fuentes empieza su novela Una familia lejana dándole corporeidad a un fantasma o a una fantasma, como se decía en tiempos de Bartolomé Torres Naharro. $Y$ es exacto, porque aquí se superponen varios fantasmas: el de la propia obra, la puesta en escena numerosa de las auras, es decir, el halo de la fantasma que se plasma en Aura, personaje femenino, pero también el buitre, o mejor, el zopilote, pues ¿qué otra cosa es un aura sino un ave del orden de las rapaces diurnas?; y justamente Branly es un hombre viejo y pálido, «hijo y hermano» del siglo $\mathrm{xx}$, convertido en hombre con «espesor", con "presencia carnal», gracias al sol de México, que a su vez se alimentaba de sangre. Branly disipa su aspecto de «fantasma civilizado» con un viaje a la pirámide de Xochicalco, viaje que sirve a la vez como viaje por las edades, ejercicio practicado con placer por Carlos Fuentes, pues le permite utilizar viejos medios de transporte y porque puede incursionar en la historia, unir sin problemas las geografías y sobre todo revivir en un libro las influencias, aquellas que pasan como fantasmas por el tejado (otra vez Torres Naharro) y que los críticos policíacos persiguen con afán conandoylesco. A menudo oímos en rumor y vemos en letras las acusaciones: Aura revive, plagia, recuerda Los papeles de Aspern de Henry James; sí, decide Fuentes; sí, dice Branly, su alter ego, «Hay otra narración contigua, paralela, invisible de cuanto creemos debido a una escritura singular. ¿Quién ha escrito la novela de los Heredia? ¿Hugo Heredia en las ruinas de Xochicalco o el rústico propietario del Clos de Renards? ¿Yo que se la he contado, usted que algún día contará lo que yo le he dicho o alguien más, un desconocido? Piense otra cosa: la novela ya fue escrita. Es una novela de fantasmas inédita que yace en un cofre enterrado bajo la urna de un jardín o entre los ladrillos sueltos del cubo de un 
montacargas. Su autor, sobra decirlo, es Alejandro Dumas. Vaya tranquilo, mi amigo. Yo sé sobrevivir al terror: «El amigo es Fuentes, inscrito ahora en su propia novela oyendo un cuento - varios cuentos-, cuentos que recorren viejas páginas leídas en la infancia o en otra vida de otra infancia. Carlos Fuentes es Branly al enfrentarse con los espectros que primero y antes que nada son los libros, seres sin carnalidad, sin espesor, apenas el del amarillento color y textura del pergamino, color que más que la palidez ostentan los viejos, así sean tan vitales como Buñuel, a quien se dedica este libro en honor de su cumpleaños, o el de la editorial Era, que también celebra su cumpleaños en el año 80 , y lo festeja editando a sus viejos amigos, los primeros publicados en su imprenta.

Y si el cumpleaños es importante, primero como título de una novela publicada hace ya varios años y luego como signo del paso del tiempo, es porque marca una historicidad. Buñuel va con el siglo y Branly también, es hijo de él, se hermana a su acontecer, aunque entre él y la escritura haya una mediación. La mediación que obligaba a Constant a encontrar un manuscrito en un albergue: mediación que en Potocki se convierte en maldición.

Y no existe literatura sin maldición ni tampoco sin mediación. Aquí la mediación es aparentemente descartada, of recida en bandeja a los ojos del lector, que a su vez la oye trasladada a la voz de un narrador que va desenrollando un manuscrito hijo y nieto de otros manuscritos luminosos como antecedentes.

Luminosos, sí, porque forjan una tradición clásica y viva, una tradición que es a la vez, primero, con las palabras de madame de Lafayette, «una especie de agitación sin desorden», y luego, citando a Proust, «son flores envenenadas entrelazadas con joyas preciosas». La luminosidad surge de la ordenación, de lo civilizado; la mediación, del entrelazamiento de lo corrupto, lo envenenado, con la joya; y la alianza de la agitación, con la pericia de la orfebrería se cumple en la mediación, ¿y qué será la mediación?: un jeroglífico.

Fuentes muestra sus cartas, las pone sobre la mesa elegante, supercivilizada de un club selecto donde conversan dos amigos comiendo y bebiendo un vino de Sauternes hecho de uvas casi podridas; Fuentes está oyendo una historia que luego pondrá ante nuestros ojos manuscrita por él, como antes puso ante nuestros ojos una historia encontrada en un viejo albergue suizo el viejo Constant, o también ese contemporáneo del taimado autor de Adolfo, el noble polaco que escribía en francés y fue a encontrar un manuscrito perdido en Zaragoza, publicado siglo y medio más tarde por Roger Caillois. Todos son fantasmas, pero con voces muy 
presentes; todos los manuscritos son sus hijos, como es hijo Fuentes del viejo Buñuel y del Conde de Branly, supuesto narrador del primer texto recontado por Heredia y recopilado y dado a la luz por Fuentes. Así se montan tres versiones del relato y se define el carácter ficticio de la creación: «figura creada por la imaginación narrativa, pues sólo ella es capaz de reproducir algo verbalmente, así sea incompleto, así sea aproximativo. Esa proximidad incompleta será de todos modos la única verdad posible». El relato del Conde de Branly se cuenta a mediodía y el sol de Xochicalco brilla sobre él. Luego empieza a caer la tarde y también en el relato nacen las penumbras.

Me preguntó si aceptaba esas condiciones, y le dije, sin remedio, que sí; jamás había leído o escuchado una ficción sin acceder al pacto que mi amigo, en esta cima vibrante, aunque peligrosa, de nuestro contacto efectivo e intelectual me ofrecía. Pero iera posible un acuerdo así entre dos amigos presentes, como lo era entre un lector y un autor fatalmente distantes?

El relato de Branly es el relato padre, el que engendra el relato que contará Fuentes para salvarse de una maldición, la que cae sobre el que revele al último el relato. Pero también el relato define la mediación que existe entre el que cuenta y el que lee y el misterio de una historia donde el tiempo entrelaza las memorias y las hace fantasmas. De este modo, el texto se entrelaza a las viejas fuentes, esas lecturas continuas ejercidas por un hombre civilizado y de una cultura clásica. Pero también esas lecturas se entrelazan con las de un mexicano transculturado a la cultura francesa que opone el desorden selvático de su realidad a la agitación sin desorden de lo europeo. A medida que el relato se desarrolla, se van abriendo las cartas, no sólo las que el relato mismo va descubriendo en su necesidad de definir la historia, sino aquellas que descubren sus orígenes, es decir, los relatos clásicos que un autor moderno, y por añadidura mexicano, lee para organizar el universo de su creación.

Y si Proust y madame de Lafayette definen las oposiciones y las marcan con violencia en una sola frase engastada como una joya (aunque pleonástica porque utiliza una metáfora de orfebrería), Dumas, Balzac, Lamartine, Laforgue, Jules Supervielle, Lautréamont y José María Heredia proporcionan la carne del relato y descubren las influencias, esas influencias que luego pueden concebirse por los críticos como plagio.

Vuelvo a explicar: El viejo Branly relata una historia de coincidencias en donde se encuentran México y Francia, como alguna vez se encontraron en la violencia de la intervención francesa. La vida de Branly 
se va descifrando al tiempo que se va integrando el relato, por lo que contarlo equivale a descifrar un jeroglífico, a poner en claro un enigma. Y la historia contada atañe a una familia en la que el padre es justamente descifrador de jeroglíficos: un arqueólogo a quien persigue la muerte porque se ocupa de las ruinas y porque en su propia vida se van encadenando las tragedias. Hugo Heredia se llama el arqueólogo, y su capacidad para entrever lo que las piedras dicen, o mejor, para descifrar el relato que las piedras esconden, se enfrenta a la necesidad que tiene Branly de entender una historia que ha vivido en relación con los Heredia y que se maneja como una incógnita. Incógnita porque reúne en su acontecer varios tiempos y varias reencarnaciones de personajes, que son a la vez históricos $\mathrm{y}$, por tanto, verdaderos, pero también totalmente falsos en la realidad cotidiana, pues se gestan en los sueños y van a poblar después los caminos desvaídos y traicioneros de la memoria. Pero Fuentes no sólo cuenta una historia, la que proporciona los incidentes que conforman el relato; no, la cuenta tres veces, primero según el Conde Branly, que la relata durante una comida y su sobremesa; luego según Hugo Heredia, que añade elementos a la historia y anuda hilos sin terminarlos; para finalizar con la historia que Fuentes, autor del relato entero, pero también del relato que se cuenta con su nombre y hasta con una bibliografía sucinta: los tres relatos se entretejen en orden agitado. El orden sería, en suma, la presentación de una historia fantástica, ya lo he repetido varias veces, fantasía nutrida de incidentes cotidianos y contemporáneos a los personajes y de sueños que se convierten en realidad en la persona de un extraño latinoamericano vuelto francés. Personaje que comprime en su cuerpo no sólo la historia de varias generaciones que llevan su nombre, sino la historia de varios países del Caribe y también la de México. Pero al intervenir como personaje de la historia aclara la infancia y la memoria de Branly. También enturbia lo que toca porque su presencia puede recordar a los vampiros: Branly lo dice y Heredia demuestra que su imagen aparece en el espejo, pero en su jardín versallesco no aparece duplicando su simetría ningún espejo.

Lo importante no es descubrir otro vampiro más, ya Aura demostró la capacidad de Fuentes para añadir vampiros a la literatura; lo fundamental es demostrar que toda la literatura está hecha de la sangre de los otros, del robo, del plagio, y el jeroglífico se resuelve de otro modo: Fuentes es el plagiario, peor, es el vampiro, pero por partida por lo menos doble. Su relato se nutre de los cuerpos de otros relatos, exhibidos como la carta robada de Poe (muy citada en el texto) ante los ojos de los descubridores de entuertos detectivescos, y es también la historia concentrada de todos los demás cuerpos de ficción que el propio Fuentes 
haya pergeñado. Es, en síntesis, una mirada crítica sobre la propia trayectoria, el deseo de advertir desde lo alto de una pirámide narrada los abismos y las fallas de una productividad producida a lo largo de varios lustros. Si Branly busca a sus padres y se detiene en un retrato de un joven de treinta años, puede ser padre de su padre, como Carlos Fuentes es padre de todos los relatos que ha engendrado gestándolos con la sangre proporcionada por sus antecesores revelados y por los que puedan inferirse de nuevo del relato; por ejemplo, Lowry, sus abismos y sus barrancos y los perros y los zopilotes y, claro, Cuernavaca.

La pirámide está trunca, sin embargo. La confesión del crimen no basta para disculparlo; tampoco para descifrarlo totalmente. El otro crimen es la bastardía. La incompletez de Latinoamérica: su relación con Europa, el enfrentamiento de los jardines pulidos y las salvajes selvas, la civilización y la barbarie. También la aceptación de una transcultura y el continuo ir y venir de las carabelas: los indianos son seres híbridos, nunca identificados consigo mismos, y entre ellos hay muchos poetas: Jules Laforgue, Jules Supervielle, Issidore Ducasse, conde de Lautréamont, salidos de ese Uruguay mitad europeo, mitad hirsuto que produjo los Cantos del Maldoror para romper la armonía del orden sacando a luz el origen de la agitación, y que bien podría caber en esta descripción:

Y el jardín propiamente dicho, la disposición precisa de arbustos, pensamientos y pastos en una especie de arabesco de alcachofas y rosales cuya geometría, a medida que descendía esta primera lluvia pertinaz del otoño venidero, se revelaba brutalmente desfigurada por una herida honda y prolongada, un navajazo en la jardinería razonable y perfecta, una irrupción de la selva en este espacio diseñado para negarla: desde las hojas caídas, sobre la grava, entre el pasto y los arbustos, la lluvia revelaba, como en una solución fotográfica, una trinchera indecente, una marca tajante y oblicua en el rostro del jardín, el jardín desfigurado por algo semejante a la huella de una bestia nocturna, secreta, acechante.

Esa huella y el deseo de borrarla está quizá en ese José María de Heredia, autor de Los trofeos, «el francés de La Habana, el conquistador entristecido que regresa al viejo mundo cargando con fatiga las altaneras miserias de sus trofeos, la bestia expansiva y la flora viviente, el sol bajo el mar y los temblores de oro». Así, los Heredias que van y vienen desde Europa a América y de América a Europa descubren las insignias de una monstruosidad y un salvajismo que descuaja y envenena cualquier orden: son vampiros teñidos de salvajes.

La constante relación entre Europa y América se marca en el cuba- 
no Heredia, heredero de ese otro Heredia, prerromántico, que también naciera en Cuba y escribiera el teocalli de Cholula, confrontado, como Fuentes, a las dos culturas: la civilizada y precisa y la selvática y sangrienta. Entre las culturas y los poetas, siempre una mujer - Cherchez la femme-, también objeto policíaco, y los vampiros y los personajes en busca del tiempo perdido se detienen en un cuerpo, vestido a la moda del Imperio, de una mujer que viaja en sentido inverso por la geografía y por la historia y que al llevar con ella las viejas canciones de ronda francesas las entronca, las entrelaza con las que América produce, y à la claire fontaine que cantan los niños y los barrancos se opone el cantar de la llorona que ayer maravilla fue y ahora ni sombra es. Pero en una novela de fantasmas las sombras encarnan en imágenes pintadas que cobran cuerpo y en cuerpos muertos que resucitan en la vida y en los sueños y que se convierten en patrimonio de los tres relatos, en su hilo conductor, en la imagen renovada de la mujer que llora siempre, recordando a sus hijos con los ojos encendidos y con los cirios clásicos de los velorios. Hijos y padres se encuentran en la madre loca, en la llorona, y en ella se concentra el entrelazamiento que hace posible el veneno y las joyas, la pirámide y el faubourg Saint Honoré, el barranco selvático y el jardín pulido. Y también la radiografía de la creación, la puesta al desnudo de una producción, el revés de la escritura, su tramado y el descubrimiento de que lo visible se torna invisible; en suma, destaca la identidad de un escritor que se ha enredado en su propio laberinto. 